\title{
Overview Of Rules Governing Attribution Profits Generated From Permanent Establishment
}

\author{
Mohammad Abdul-Jalil Hamdan, Ph.D \\ International Law, Xiamen University, China
}

\begin{abstract}
In regard to the attribution of profits; this article concluded that there are still some uncertainties on the categorization on the taxation of the cross border businesses. Therefore, the OECD MTC has tried to harmonize the problem by employing some factual and functional evaluation of the challenges in the internal dealings. However, some countries mostly in the European Union had different methods that help in dealing with these problems. The paper on the other hand has tried to evaluate the solution in both treaty and non-treaty cases so as to achieve an amicable solution towards the same. In addition, the problem of double taxation still derives varied opinions by different commentaries by the United Nations and the OECD. The approach that has being proposed by the OECD MTC recently does not cover all the required areas of the problem. The hypothetical evaluation by the organization still faces some notable drawbacks in its implementation. The measures that have been employed so far do not uphold certainty to the individual taxpayers and businesses. Hence, the reliance of the authorities and business in these cases on documentation has been excessive. The paper establishes that the most ideal systems that would solve the current tax challenges are the one that would logically look at the inconsistencies observed in taxation. Therefore, the chapter proposes international discussions and agreements by use of a common and comparative law as the best way to achieve the desired taxation objectives. Thus, in order to protect the sovereignty of the countries and to ensure and confirm tax neutrality and fairness between source and residence countries, we are urgently in need to modify the current system of international taxation standards in accordance with new e-commercial environment. Furthermore, in pursuant to the basic principles of international tax law and to find better and essential solutions to the e-commerce issues relating to attribution of profits.
\end{abstract}

Key Words: Permanent Establishment; E-Commerce; OECD MTC.

\section{INTRODUCTION}

The concatenation of national markets and economies has recently been in the increase in the past decade and this has resulted in unimaginable impairment on international policies on taxation. The loopholes in the existing tax laws have resulted to profit shifting and base erosion and thus calling for a solid move by the tax policy formulators to reinstate the status of the systems. G20 and OECD MTC members' states took a step of adopting the 15 detail action plans so as to handle the BEPS issue in 2013. Three action plans had been pinpointed on three major purposed pillars regarding: enhancing the quality of the existing domestic policies that directly influence the consistency of international operations, encouraging material requirements for the cross-border standards, and enhancing transparency and certainty in the respective business operations.

Therefore, the BEPS package was one of the steps that signified the desire to freshly renovate the existing international tax policies. The package was well consolidated and comprehensive enough to handle some of the tax issues in this century. There is thus some hope that once such measures are adopted, the poorly formulated and outdated taxation structures will soon be 
rendered irrelevant. This decade expects that business incomes will be timely reported. Therefore, as a result, the Permanent Establishment concept has also gained momentum. There has been various wording at the multinational stage that has been initiated by the League of Nations in subsequent years starting from 1927.

Article 7 of the OECD Model Tax Convention established the attribution profit rules to a permanent establishment. However, these policies were also integrated in the UN's model for double taxation both for the developed and also developing countries ${ }^{1}$. The permanent establishment threshold was initially made up of two distinct elements; the fixed location from which the enterprise activities are partially or else wholly are carried out, and the business' operations on the behalf of the management alongside using the entity's legal name in concluding and servicing contracts.

However, both cases require the business to have some physical presence either through the direct operation of the business entity or else via a dependent agent. There has been some advancement in the models so as to accommodate the periodical changes of the conditions influencing a business activity. In an illustration, many bilateral treaties affecting the service industry has put into consideration the cases in which the engagement of the non-resident business employees in the provision of services would justice the imposition of taxes at the source; when the services provided last for a given time period. This consideration is made regardless of whether the activities take place in a fixed location or not ${ }^{2}$.

The adoption of these emerging business models that are highly dependent on the information technologies that erupt day by day creates a good illustration of how modern businesses are being operated. However, the big worry remains on how effective the current treaties are in handling these modifications that are being experienced day after day.

The chapter would try to look into the currently governing policies and rules on matters regarding the apportioning of profits under the concept of permanent establishment as mentioned by OECD's Article 7. Moreover, the chapter also would discuss the existing treaties regarding the same and also assess the issues that influence the treaties and the associated commentaries.

\section{ATTRIBUTING PROFITS TO A PERMANENT ESTABLISHMENT UNDER THE ARTICLE 7 OF THE OECD MODEL TAX CONVENTION}

Article 7 of the model establishes the apportioning of taxation rights in relation to the business profits realized by any business in the contacting country. In addition, the model includes the basic policy that unless the business in the contracting country is established to have a Permanent Establishment that is located in another country, the profits that are realized by the business are not subject to tax by the other country unless they are classified to have a permanent establishment in that country ${ }^{3}$.

The practices by the countries that are members of the OECD Model Tax Convention and also those that are not part of the tax convention depict differing attitudes and responses in regard

\footnotetext{
1 http://www.oecd.org/ctp/transfer-pricing/1923028.pdf

${ }^{2}$ Aless, A., j. DE Goede and W. Wijnen (2011), "The Treatment of Services in Tax Treaties", Bulletin for International Taxation, 2012, Vol. 66, No. 1.

3 OECD Transfer Pricing Guidelines for Multinational Enterprises and Tax Administrations 2017, OECD Publishing, Paris http://www.oecd.org/tax/transfer-pricing/oecd-transfer-pricing-guidelines-for-multinational-enterprisesand-tax-administrations-20769717.htm
} 
to Article 7. The Fiscal Affairs Committee established the guidelines that required states to promote in taxation certainty for the taxpayers. The measure signaled that principle of arm's length would be adopted by the idea of permanent establishment. The process emerged in a report in 2008 that discussed the apportioning of profits realized by business Permanent Establishment ${ }^{4}$.

Article 7 establishes that the contracting country does not have any rights to subject the profits realized by a business entity of another contracting country not unless the activities are conducted in respect to the Permanent Establishment that is contained therein. The previous article got adopted in 2010. The 2008-revised brand of the report was also adopted to enable harmony in the conclusions of the report and to incorporate the modified wording and numbering of the version. However, the interpretations and the conclusions observed in the 2010-revised report is somehow identical to the reported drafted in 2008.

As the first paragraph reads, there is some incorporation of the taxing rights allocation in regard to the profits that are realized by any business in the state it operates from. Foremost, the paragraph establishes that unless the business has been established to have a PE that is located in another country, the profits hereby mentioned are not subject to taxation by another country. Then the paragraph states that; in the case in which the business in question carries out its activities in the other country by using a PE that is found in that country, then it is automatically subject to taxation by the other country.

Therefore, the first paragraph can be understood to try restricting the taxation right of the contracting country in regard to the profits that are generated by the businesses. The paragraph however doesn't restrict the countries to subject their residents who work in with the foreign business entities to taxation by using their domestic taxation laws. These countries may base their policies on the residents' engagement in the activities that are attributable to tax.

The second paragraph establishes the primary rule that helps in the determination of the business profits that are taxable by basing on the idea of permanent establishment. In regard to this paragraph, the profits are the earnings that the PE will be expected to generate in the case in which it operates independently and in a separate position but participating in the same business activities under the same business environment. The paragraph puts into consideration the risks that influence the operation of the business assets by the PE. The paragraph moreover specifies the relationship between the PE and the components of the businesses in operation.

The primary approach that has been integrated in this paragraph aims at establishing the profits that are taxable in relation to the permanent establishment. Therefore, the evaluation of the taxable income under the permanent establishment idea is independent of the other parts of the businesses. The other portion of the fiction also tries to refer to the principle of arms' length as specified by Article 9 so as to adjust the generated business profits.

The third paragraph establishes that the calculation of the business profits in a given permanent establishment will be susceptible deduction of the incurred costs for the sake of Permanent Establishment. Some of the expenses that may be experienced include some general and also executive administration costs found in the country where the permanent

${ }^{4}$ OECD, Report On The Attribution of Profits to Permanent Establishments 2008, OECD Publishing, Paris. https://www.oecd.org/tax/transfer-pricing/41031455.pdf 
establishment is found or even elsewhere. The paragraph is applicative only in the cases where there are differences in the establishment of the taxable incomes attributable to a given PE due to the conformity of the business.

The fourth paragraph on the other hand tries to broaden the definition of the term 'profit' in which it specifies that the term include all the incomes that are generated by all the undertakings of the business enterprise ${ }^{5}$.

\section{EXAMINING ISSUES SURROUNDING THE PE INVOLVED THROUGH E-COMMERCE TRANSACTIONS}

This section tries to handle the common issues that influence permanent establishment in the context of electronic commerce. In addition, the section will look into the issue of profit attribution to a given Permanent Establishment indulged with transactions using ecommerce. In accordance with the existing definition of permanent establishment by OECD Model Tax Convention as illustrated initially; PE should include the place of carrying out the business which in essence should be fixed and all its operations carried out from that fixed location. This notion is however different from the context of electronic a business activity since it is not yet established where there business really exists ${ }^{6}$. The Internet in its own is not only a single place, but also developed components. For this reason, the authorities find it challenging in establishing the specific components of the business entity that are attributable to tax ${ }^{7}$.

The traditional business environment was characterized of fixed business locations that were easily distinguishable in the foreign states where the businesses operated in form of factories, plants and offices.

Another shortcoming to application of e-commerce components to existing tax rules just like the first element. E-commerce with a computer server fails to serve the second element's purpose, hence the server's fixedness is immaterial and its inerrant employee can enhance mobility of a server from and within towns, cities and buildings, because the server is mobile just like a portable computer and function perfectly. In addition, tax evasion can be achieved by employing immobility where the business stays in a fixed place; website information can be simply moved within and between servers. Furthermore, a warehouse for storage, display, or delivery has no contribution in permanency of a business therefore lacking permanent establishment and a server that stores and delivers information can be considered as an electronic warehouse.

If functions of a server constitute activities that aim on preparation of other auxiliary functions, the server will be termed as permanent although it may be in a fixed location in which the business is run. This necessitates the analysis of the activities performed by the server. The server may fail to create a lasting establishment if its sole function is provision of information or advertisement. Contrary to that, a server that performs essential functions of a business, its establishment will be permanent. For instance, a server that concludes contracts with clients, prepares and makes payments, and makes automatic delivery of products comprises vital functions and surpasses activities, which merely prepare or aid in preparation. This will therefore be part of a permanent establishment. Due to difficulty of application of e-commerce

\footnotetext{
${ }^{5}$ OECD, commentaries on the articles of the model tax convention, http://www.oecd.org/berlin/publikationen/43324465.pdf

${ }^{6}$ Srivastava, D.K., 2018. Taxation of E-Commerce: Problems and Possible Solutions. In Contemporary Issues in International Law (pp. 447-457). Springer, Singapore.

${ }^{7}$ See discussion supra Part II.A; supra note 18 and accompanying text
} 
in the current Permanent Establishment definition, e commerce should be localized to serve as a solution and this will be discussed later ${ }^{8}$.

\section{ATTRIBUTION PROFITS RELATED TO THE PERMANENT ESTABLISHMENT IN THE E- COMMERCE TRANSACTION}

OECD proposed "server permanent establishment" to counter problems faced as a result of e commerce. As discussed earlier, numerous issues surround server PE, it is easily portable and gives room for taxpayers to avoid or reduce the taxes they should pay'.

For instance, a US based online music company called FutureMusic.cn looks forward to expanding its sales to clients in the Middle East; it may setup a server in Bahamas where corporate income tax is low in comparison to similar target markets. FutureMusic.cn may ensure that sales of digital movies files (AVI files) can be done cross border by ensuring that their software can manage to make sales to clients located anywhere within the Middle East countries. This software; which is located in Bahamas can therefore use the website to advertise movies, collect orders and ensure payments are processed before the movies are transmitted to the end user.

OECD MTC proposed that the server should be a PE that entitles Bahamas to tax profits resulting from the server's operations, which makes little sense because FutureMusic4U is not located in Bahamas, which is also not where they actually made sales. Traditionally, taxes should be paid to the country where the business is located or incorporated or on an equal measure to the country in which the business activity took place.

The nature of the Internet makes the use of computer server as a traditional physical presence to fail. Attention is focused on the software functions that are performed within the server by the server/PE to establish if requisite threshold of the server's activities has been surpassed. Software functions will therefore determine how the income generating functions should be allocated which can be shifted anywhere in the world which may involve some transaction costs, however, this cost are occasionally low.

\section{CONSIDERATIONS IN ATTRIBUTING PROFIT REGARDING THE PERMANENT ESTABLISHMENT USING THE E-COMMERCE ENVIRONMENT}

The Internet has changed how business is conducted in local, national, and multinational environments. Through the development of various information and communication technologies, the Internet offers a reliable, consistent, secure, and flexible communications medium for conducting business. Whilst the use of the Internet as a marketing and sales tool receives the most publicity, the more significant economic consequences of the Internet arise from the ability of enterprises (including those in traditional sectors) to streamline various core business functions over the Internet ${ }^{10}$. Business functions such as product innovation, production (including delivery of services), administration, accounting and finance, and customer service have all been made more efficient through the use of new communications technologies ${ }^{11}$.

\footnotetext{
${ }^{8}$ Monica Gianni,The OECD's Flawed and Dated Approach to Computer Servers Creating Permanent Establishments 17 Vand. J. Ent. \& Tech. L. 1 (2014), available at http://scholarship.law.ufl.edu/facultypub/608

${ }_{9}^{9}$ Yapar, B.K., Bayrakdar, S. and Yapar, M., 2015. The role of taxation problems on the development of e-commerce. Procedia-Social and Behavioral Sciences, 195, pp.642-648.

${ }^{10}$ Neubig, T.S. and Slemrod, J.B., 2017. A Tax-Systems Perspective on Recent Global Tax Initiatives

11 OECD, Are the Current Treaty Rules for Taxing Business Profits Appropriate for E-Commerce?, Report,

www.oecd.org/tax/treaties/35869032.pdf
} 
The following is an illustrative list of various categories of business models and functions enabled or impacted by the advent of Internet-related technologies. These examples provide the background for the work of the TAG, which took them into account when discussing how the existing treaty rules for taxing business profits, as well as various possible alternatives, would apply to electronic commerce ${ }^{12}$ :

Outsourcing: new communications technologies allow enterprises to outsource the provision of services and to reach new suppliers of components and materials. A principal effect of outsourcing is to reduce costs for the enterprise, as the outsourcing service provider normally can provide the services, components and materials at lower cost than the enterprise, due to greater functional specialization, lower wage costs, or other factors.

Commodity suppliers: The supply of raw materials is greatly facilitated by web-based systems that streamline the ordering, selling and payment systems for both small and large sellers/purchasers.

Manufacturing: New information technologies allow manufacturers to substantially reduce procurements costs. In turn, this allows their suppliers to access new customers or markets and reduce their transaction costs. These technologies also enable manufacturers to increase their direct sales to consumers, for instance by facilitating custom ordering of products. Similarly, they facilitate the outsourcing of non-core activities, such as manufacturing, of many product suppliers. Traditional manufacturers themselves can outsource manufacturing of components to lower cost locations.

Retail distribution: Through their web sites, enterprises may provide low cost products with a high degree of convenience and customization for their customers. Many business functions (e.g. procurement, inventory management, warehousing, shipping etc.) may be automated. Electronic marketplaces (e.g. online consumer auctions, electronic marketplaces operated by content aggregators or online shopping portals) allow consumers new ways to buy products or compare prices.

Delivery: Shipping enterprises benefits from new technologies (e.g. online parcel order and tracking systems), which allow quicker and more accurate deliveries. This allows their business customers to outsource order fulfillment functions in order to concentrate on core activities.

Marketing and customer support: Through the Internet, enterprises can present information about their products or services to a larger audience in a more efficient and cost-effective manner. This allows small and remote businesses to enter new markets. Customer support also greatly benefits from new technologies, which allow worldwide access to call centers and customer-related operations, which can be provided by any jurisdiction that offers an educated and highly skilled employment base or presents cost-effective opportunities.

Information: New technologies have made possible a vast array of new approaches to the delivery and treatment of information. Computer networks such as the Internet allow worldwide and almost instantaneous delivery of information in various forms to individuals and businesses. E-learning and interactive training allow a more generalized access to education and training, whether general or labor-oriented.

12 OECD, Are the Current Treaty Rules for Taxing Business Profits Appropriate for E-Commerce?, Report, www.oecd.org/tax/treaties/35869032.pdf 
Financial Services: Financial services, such as banking, brokerage and life insurance, are now routinely offered through the Internet. This can be done by traditional financial institutions or by new businesses, which can now enter markets without incurring the enormous expenses of setting up a brick-and-mortar branch network. Further, financial institutions can now offer new functions related to the security of e-commerce transactions.

Digital products: Various digital products (e.g. software, music, video, games, news, e- books, etc.) can be marketed and, in some cases, distributed through web-based systems in direct purchase, rental, or pay-per-use transactions.

Basically the current taxation rules of the business profits regarding the e-commerce are applicable in a variety of ways. This can be attributed by the place of management, which effectively addresses the concept of permanent establishment, the profit on the server and the transfer of pricing. While considering these, there are significant bilateral treaties and some principles, which guides on how the businesses are taxed on their profits in a relatively uniform way. This means that if a resident is liable to give out tax then the extent of relevant income in that country is dependent on that taxpayer. In general, for any resident to be recognized as a potential taxpayer, he or she must be having a liable income from known industry.

Therefore, there is the need to adjust financial status in order to qualify to be imposed taxes. However, paying taxes is not something credible, of which somebody can be happy. There are instances when a resident has to be taxed in his business but for those individuals who do not belong to that country, then, the tax is deducted in their business profits, which may be found in that particular country, and their business establishment has been in existence for several years.

In case there is need for treaty purposes, the resident is liable for a liability to be enabled to tax under the domestic law regarding that taxpayer. For any company or resident to be considered as liable to pay tax has to establish his outstanding income specifically from his business accrued profits or from his employed institution. This is very important since no government can impose taxes to individuals who are not working. There are some domestic factors, which can initiate a company to make payment to taxes into different countries, but specifically this is done when two countries have entered into treaty with one another. This is significantly aided in an inclusion called, "tie breaker" regulations to ensure a company or any able taxpayer is having a single residence for the purpose of applying the treaty. This rule, tiebreaker confirms to the OECD tax model to provide convention of an effective management regarding the country of the resident choice to pay taxes ${ }^{13}$.

The permanent establishment is also vital in checking whether the source rule and the entire non-resident business profits are corresponding to the attributed establishment of the permanent source of information. The permanent establishment defines the business environment in which any up growing business enterprise partially or wholly carries a geographical requirement by identifying the incorporated establishment procedures. This means that for the business to thrive in hectic environment, the owner has to reconsider on the payment of taxes according to the laid down rules by OECD.

13 OECD, Are the Current Treaty Rules for Taxing Business Profits Appropriate for E-Commerce?, Report, www.oecd.org/tax/treaties/35869032.pdf 
The main researches have stipulated a number of strategies, which are carried in the ecommerce. They include:

a) The websites, which hosts the services, accordingly has to be automated to ensure traffic generation for the benefit of the customers. However, this does not incorporate the PE, which carries their businesses through the hosted websites ${ }^{14}$.

b) Some circumstances do not allow the PE rule in the Internet service providers (ISP) this is because they do not institute the enterprises of the agents of the unusual service providers.

c) An online e-commerce platform for instance the website cannot be an enterprise by itself.

d) Computer equipment's for instance, server is usually located in a certain circumstance, this can constitute to the establishment if the PE which can thereafter require functional preparatory beyond the unexpected auxiliary.

Almost all the treaties in the above are developed with the essence of creating profits.

In summary, emphasis will be particularly put on four issues which enhance the way in which the present treaty rules on taxes imposed on profits realized by businesses in electronic commerce, that is; the Permanent establishment idea, the process of transfer pricing, the apportioning of profits in relation to permanent establishment and the management location.

Although the differences observed between bilateral tax treaties are significant, there is relative uniformity in principles underlying provisions that govern taxation of business profits as stated in the treaty which can be summarized as follows.

\section{Liabilities to A Country's Tax: Considering the Residents and Non-Residents}

The liability to taxation is contingent on where the resident drives the income, i.e. whether in the country of residence or not. Besides, liability to tax payment depends on whether the taxpayer lives in the country or elsewhere ${ }^{15}$. In this kind of taxation, anyone is liable to taxation on benefits derived from businesses ${ }^{16}$. But non-residents investors who pay taxes on their profits to a degree that they are attributable to be established permanently in the country. Liability to tax as specified in domestic law determines the residence of the taxpayer for the treaty purposes.

A company may be termed as resident to two different countries that entered to a treaty as a result of reference to the domestic factors, therefore tie breaker rules (rule of OECD model tax convention providing that residence of a company is determined by the pace where effective management takes place) can be included in treaties so that the taxpayer can only have one country of residence.

Permanent Establishment: The Treaty Nexus for Taxing Business Profits of Nonresidents The right of a country to impose taxes with regards to profits of taxpayers who are nonresidents is determined by the idea of permanent establishment that regards nexus/threshold

\footnotetext{
${ }^{14}$ Bruins et al. (1923), Report on Double Taxation submitted to the Financial Committee, No. E.F.S.73.F.19, League of Nations, Geneva

15 Kane, M.A., 2017. A US Perspective on the Relevance of the OECD BEPS Project to the Taxation of Nonresidents. New Zealand Law Review, 2017(2), pp.175-205

16 Srivastava, D.K., 2018. Taxation of E-Commerce: Problems and Possible Solutions. In Contemporary Issues in International Law (pp. 447-457). Springer, Singapore.
} 
rule, which also clarifies the rules used to tax profits realized by businesses ${ }^{17}$. The PE also performs as the major rule to a degree that taxation can only be imposed on the profits realized by businesses, which could be attributed to a PE.

A place on which a business is wholly or partly fixed carried out a according to the PE definition i.e. the location where business activities take place should be termed as a PE; this also includes the time requirements to be able to make conclusions that a business enterprise is partly or wholly exercised through a particular place, the place should be readily available to meet the needs of the business. However, the treaty clearly defines that for an establishment to be termed permanent, its location should only be for preparatory or auxiliary activities; the place will not constitute PE irrespective of the definition.

Questions have been raised concerning how the current treaty definition of the Permanent Establishment should be defined. The OECD has provided clarifications on which way it considers these definitions could be applied to the electronic commerce operations ${ }^{18}$. The following conclusions were reached: the first conclusion established Websites that host services do not result in a PE for the business that transacts through the hosted website. Also an Internet provider -in regard to the rules described above- wouldn't be deemed to constitute a PE for the businesses to which it provides services except in exclusively unusual situations; A website (in itself) cannot perceived to make a PE, and lastly the services offered at places where the computer equipment has been located should go beyond the auxiliary or preparatory so as the place should constitute a permanents establishment.

Contrary to that, majority of the treaties provide that profits from marine vessels and aircraft in international traffic may be exempted from taxes from countries of origin although that is where their Permanent Establishment located in.

Treaty rules, which are laid down by the OECD, have a wide source of information; this means that they have the similarity in terms of taxing the business profits and the residents of that country $^{19}$. But for some cases, the same profits can be taxed to complete the countries claims. It is very important here to generate high quality standards whenever there is need to prioritization. The income generated together with treaty grants develops a number of taxation ${ }^{20}$ rights regarding the way the residents should manage their businesses' profits and any other form of income in their work. The prioritization over the permanent establishment on the separate distributives, some genuine products can be taxed due to its jurisdiction prowess even if there are no alternative thresholds met in the process of satisfying the permanent establishment. Therefore, the threshold may categorize several instances, which should be viable for the success of PE rules. These include;

$\checkmark$ Certain payments which are gained as a result of making profits in the business, interests, dividends, and technical fees allows a country to levy limited withholding taxes. This means that in case there is the need to develop a strategic plan regarding the

\footnotetext{
17 Cui, W., 2015. Taxation of Non-residents' Capital Gains. United Nations Handbook on Selected Issues in Protecting the Tax Base of developing Countries, pp.107-154.

${ }^{18}$ Lincoln, I.V., 2017. Approaches to Attribution of Profits in International Corporate Permanent Establishments' Taxable Separate Entities.

${ }^{19}$ Beretta, G., 2017. The Brisal and KBC Finance Decision: Once Again the CJEU Assesses the Compatibility with EU Law of Gross Withholding Taxation of Non-residents. EC Tax Review, 26(4), pp.193-200

20 Alejandro Vesperinas Juan, OECD RELEASES DISCUSSION DRAFT ON ATTRIBUTION OF PROFITS TO PES, 2017, https://tpinttax.wordpress.com/2017/08/09/oecd-releases-discussion-drafts-on-guidance-on-profit-splits-andattribution-of-profits-to-pes/
} 
wise ways of securing the profits and reducing on the amount of items to be selected, the taxpayer incorporates some guidelines related on the production and processing of his products.

$\checkmark$ Immovable properties also incorporate some incomes, which can be taxed by the origin country where they come from. Therefore, if the immovable properties are not within the country of origin, then, there is no way they can be taxed unless they are transported to the original country.

Outbound payments of interests, royalties and dividends can be met by ensuring all the taxpayers meet the rules laid down by the OECD regarding on the payments of the taxes. Therefore, most of the countries impose taxes regarding the domestic law on each gross basis. This does not include reductions of the expenses by any means of withholding tax. Bilateral treaties mostly specify the rate at which such withholding taxes can be imposed.

\section{Computation of Profits}

Principles regarding the computing businesses profits may be taxed, due to their similarity in terms of taxing rights, in businesses profits and all the other business processes ${ }^{21}$. Here, the taxpayer resident is attributable to generalized permanent establishment, which resides all the entities in the whole accounting firm ${ }^{22}$. Thus, the principle managers of business organization have to shortlist the workers who are viable to get subsidized salaries and their amount the equitable manner.

The permanent establishment comes to be vital through highlighting all the working processes in the business and all the potential employees who can be able to pay taxes accordingly. Therefore, every person in PE is specifically treated as a genuine taxpayer despite the relationship with all the accrued entities in any organization.

Computational profits in a multinational enterprise take the tax treaties with a provision that each subsidiary of all the groups and their transactions can be well outlined and hence easy to manage them. If the business owner is ready to trace all the intra group transactions, he or she can readjust them to reflect the prevailing independent enterprises.

The Transfer Pricing Guidelines of 1995 speculates the OECD in deep length and hence identifies the "separate entity approach as the most reasonable means for achieving equitable results and minimizing the risk of unrelieved double taxation," this strategy has a wide range of unique features. Therefore, "to apply the separate entity approach to intra-group transactions, individual group members must be taxed on the basis that they act at arm's length in dealing with each other's "and hence, this means that, "To ensure the correct application of the separate entity approach, OECD Member Countries have adopted the arm's-length principle."

\section{Current Commentaries Of Business Article (Article 7) Regarding The OECD Model Tax Convention}

There has been a big challenge historically on how the uncertain profits are attributable to permanent establishment. However, the OECD MTC knew this issue and hence, it came up with a strategic plan and addressed the issue in a documented form ${ }^{23}$.

\footnotetext{
${ }^{21}$ Miller, A. and Oats, L., 2016. Principles of international taxation. Bloomsbury Publishing.

22 Bruins et al. (1923), Report on Double Taxation submitted to the Financial Committee, No. E.F.S.73.F.19, League of Nations, Geneva

${ }^{23}$ Reimer, E., Schmid, S. and Orell, M. eds., 2018. Permanent establishments: a domestic taxation, bilateral tax treaty and OECD perspective. Kluwer Law International BV.
} 
The following are the documents, which addressed the issue ${ }^{24}$ :

I. The first report of the Attribution to permanent Establishment dated July 2008 provided a detailed guidance on how the profits can be determined under the article 7 sections 2.

II. The updated MTC (Model Tax Convention) on OECD dated 2008 amended a commentary of article 7 in the designed report. This amended report was later reformed in 2010 hence introducing a new version. This version developed a commentary of Article 7 hence incorporating 2008 profits to the already developed PEs. However, this updated version does not guarantee a complete conclusion of the 2008 report which was developed, but it allows the report aligning and wording with that of the standardized Article 7.

III. The second principle of the OECD reflects and explains the genuine methodologies of rights to tax whereby the PE extends the profits generated by the enterprise but specifically is not attributable by the permanent establishment. According to this view, there have been many differences between different geographical countries. They argue that the principle of the general force of attraction depends on the efficiency of the permanent establishment in terms of profits and income distribution to genuine clients. The attracted view is generally agreed on the basis of imposition of taxes.

Therefore, it is also worth stating that such business profits are subject to tax in the event of establishing the permanent establishment of that given business. However, these are the profits that are not referable to any of the permanent establishments. There have been different opinions by different tax authorities with others seeing the act as being some form of tax evasion. Hence this can be established as the reason why some of the tax authorities were some time back pushing for the implementation of the force of attraction principle.

In this principle, all the business forms of income which can include but not limited to interests, loyalties and also some dividends extended to its shareholders will be completely subject to tax; as long as the business in consideration has some permanent establishment in the country in question regardless of whether the profits are realized from the activities of the permanent establishment or not. Therefore, the above force of attraction makes the general rule, as had so far not being accepted by the international treaties for practice.

However, the principle has gained some recognition in the conventions that deal with the problem of double taxation recently. The OECD MTC view that the subjection of the profits that are realized by these cross-border business entities realized in the specified nations should at least refer these profits from distinct, separate and various sources in the state so as to establish a PE. However, this measure should endeavor to make use of the articles that are derived from different OECD articles for the purpose of diversity. This implies that the process of testing the viability of any permanent establishment should be strongly built on the establishments by the OECD. Hence the process of tax administration would be efficient and even easier to adapt by different business entities since the measures will have taken into consideration the compliance factors ${ }^{25}$.

\footnotetext{
24 OECD, commentaries on the articles of the model tax convention, MODEL TAX CONVENTION (CONDENSED VERSION) - ISBN 978-92-64-08948-8 - (C) OECD 2010 http://www.oecd.org/berlin/publikationen/43324465.pdf 25 Ching Khee, T. and Syrett, H., 2017. Impact of OECD Beps Action 7 Proposals on Modification of Articles 5 (4), 5 (5) and 5 (6) of OECD Model Convention-An Evaluation of Action 7 on the Future of Intra-Group Transactions and Business Models of MNEs in their Cross-Border Investments
} 
The modern day businesses are formulated and organized in some complex manner and thus they are very sophisticated when it comes to designing models to administer taxes. Many companies especially in China actively participate in overseas investments and also participate in an extensive range of business ventures and thus there is a need to have a careful study of such entities before formulating any tax models. There are some cases in which a company may decide to diversify its operations by; creation of some permanent establishment in a given state from which it can establish it production activities. In addition a separate part of the same company may be involved in the production and selling of an entirely different set of products in the same state but using an independent business agent. However, the company in question can employ the above strategies for some unique commercial rationality that may originate from the company's historical traces in its operation of businesses or management.

In addition, such a measure can interfere with the casual operations of such a business and this is against the requirements of the taxation conventions. Such businesses may also be tempted to evade the amount of taxes they are liable to by concealing some of the vital transactional elements. The Chartered Institute of Taxation offers some comments on the OECD MTC Profit elaboration in Article $7^{26}$.

The institution advised that the profits that are generated by any business entity from any source country in respect to the permanent establishment is not taxable by any other country not unless it engages in business activities that are traceable to some permanent establishment in that country. This statement is in line with the OECD MTC article 7. Therefore, the profits that are generated by any business entity are taxable if and only if, there are attributable some permanent establishment in the respective country ${ }^{27}$. In addition, the institute added that the profits are also not subject to tax if in any case the business entity carries out its activities through an agent, who is in turn independent. There are however some arguments on the same since the independent agent is deemed to give the international business entity some penetration into carrying out their activities in the country in question without being liable to tax.

Paragraph 11 then needs some more clarifications on attribution of the profits realized by a business in regard to some given permanent establishment. These clarifications can greatly help the international companies since they mostly carry out their sales operations using their independent agents and thus prior knowledge of the same will enable these companies to realize that the profits they realize from these activities will not be subjected to tax during their calculation of profits. The institute also emphasized on the need for the companies to have a well-defined documentation of the meaning of a permanent establishment. This process as the institute established, help in avoiding some confusion when determining the amount if taxes that are attributable to a given permanent establishment.

In the second aspect, this institute acknowledged the fact the principle of transfer pricing is supposed to employ the calculation of the profits that any given permanent establishment can be attributable for ${ }^{28}$. Therefore, the institute welcomed this idea as being a standalone principle for the businesses, which would enhance the transparency of the apportioning of profits. There

\footnotetext{
${ }^{26}$ According to Charted Institute of Taxation comments on its discussion latter on article 7 of OECD Model Tax Convention it emphasized different points which is important for interpreting the article

27 See OECD MC Article 7, paragraph seven; OECD, commentaries on the articles of the model tax convention, MODEL TAX CONVENTION (CONDENSED VERSION) - ISBN 978-92-64-08948-8 - (C) OECD 2010

28 Paragraphs 13, 19 and 20 of OECD Article 7; OECD, commentaries on the articles of the model tax convention, MODEL TAX CONVENTION (CONDENSED VERSION) - ISBN 978-92-64-08948-8 - (c) OECD 2010
} 
is however some business requirement that the rest of the businesses that an enterprise engages in be considered using the principle of arm's length. In addition, the terms that guide the business transactions be reviewed so that they include the arm's length principle. It is worth noting that when the business will timely make some documentation of each and every transaction in order to illustrate the principle of arm's length will be perceived as being very onerous.

Lastly, it is worth also noting that the permanent establishment is ought to be considered as being a distinct entity from the main enterprise ${ }^{29}$. This statement implies that the main business can incur losses as the permanent establishment realizes some profits concurrently. Hence this brings some sense since the business's third element would not in any case be involved in any action without making some benefits for participating. However, this can be common in businesses ${ }^{30}$.

\section{COMMENTS ON PROFIT ATTRIBUTION TO A PERMANENT ESTABLISHMENT}

The discussion draft by the OECD elaborates on how profits are supposed to be attributed to some permanent establishment as it is discussed in the model's Article $7^{31}$. However, anyone looking at the reports should take into consideration the changes that exist in the definition of permanent establishment ${ }^{32}$ and transfer pricing ${ }^{33}$ which provide the required guidance on the process of attributing profits to a given permanent establishment ${ }^{34}$.

The Dependent Agent PE (DAPE) profits are usually attributed to the businesses' location of its assets, risks and functions, which are usually regarded to some business individuals who carry out some of the important business functions in regard to the assets that are used by the business, and the risks that are mitigated. In the situations in which the activities that are carried out by the permanent establishment are on behalf of the business entity that has a nonresident state and the DAPE fails to establish some important steps that are crucial in the process of risk attribution; then no capital or risk is therefore not possible to attribute to the DAPE.

However, in the case in which the DAPE engages some notable people functions that can result to the attributing of the assets and the related risks to the DAPE; then Article 7 establishes that economic ownerships for the funding of the business's assets that are connected to the DAPE. However, the risks that are associated with the returns of the business will be apportioned to the DAPE. In the situations in which there are some business communications between the company that is of non-resident state and the business agent who is of dependent state then the analysis on the attribution of the business profits would be analyzed again. This process is

\footnotetext{
${ }^{29}$ Paragraph 15 by OECD MTC Article 7; OECD, commentaries on the articles of the model tax convention, MODEL TAX CONVENTION (CONDENSED VERSION) - ISBN 978-92-64-08948-8 - C OECD 2010

30 OECD, commentaries on the articles of the model tax convention, http://www.oecd.org/berlin/publikationen/43324465.pdf

31 (BEPS Action 7) on June 2017 for public comments" http://www.oecd.org/ctp/transfer-pricing/publiccomments-received-on-beps-discussion-drafts-on-attribution-profits-permanent-establishments-andtransactional-profit-splits.htm

32 BEPS Action 7 http://www.oecd.org/ctp/transfer-pricing/public-comments-received-on-beps-discussiondrafts-on-attribution-profits-permanent-establishments-and-transactional-profit-splits.htm

33 the Transfer Pricing Actions (8-10) https://www.oecd.org/tax/transfer-pricing/BEPS-actions-8-10-transfer-pricingfinancial-transactions-discussion-draft-2018.pdf

34 Focusing on two topics: Dependent agents and Warehouse as PE; Alejandro V. J. highlights to important key points, which are focusing on dependent Agent and warehouse.
} 
carried out so as to establish the arm's length of the business in question in regard to the dependent business agent. In such cases the OECD thus proposes that the business in question should apply the concept of transfer pricing in order to determine the amount of tax that is attributable to a given PE in respect to the non-resident business. However, this process would be very efficient if first transfer pricing then carries it out.

If that were the case, the OECD proposes that it would be most efficient to apply transferpricing rules before moving to an analysis of the profit to be attributed to the PE of the nonresident, hence, "this process would provide the arm's length fee deductible in the DAPE in respect of the functions performed by the DAPE"35.

Also Permanent Establishment related warehouse as fixed place of business PEs. Based on the attribution of profits, activities that are genuinely not covered by the exceptions in Article 5 (section 4) of the MTC, the Permanent Establishment in these warehouses speculates the Draft. This highlights whether it is relevant for people. Functions are being performed in the country in which the warehouses are being based:

If no significant people functions are performed, the profits attributable to the PE essentially reflect the reward for the economic ownership of the asset and the routine functions performed at the warehouse. If significant people functions are performed in the country in which the warehouse is situated, this should be reflected in the profits attributable to the PE.

Alejandro Vesperinas Juan concluding his comment summing up, the discussion draft focuses on the concept of PE as DAPE and the existence of a warehouse as fixed place. In both topics, the core analysis to be performed should be the significant people functions performed by the $\mathrm{PE}$, to attribute a level of adequate profit. Also, in the case of settling a resident PE of a nonresident company, rules of art. 9 MTC should be considered." ${ }^{36}$

\section{CONCLUSION}

In regard to the attribution of profits; this article concluded that there are still some uncertainties on the categorization on the taxation of the cross border businesses. The following requirements have to be fulfilled in both international and domestic levels:

In the international level

1. International Internet law must be legislated to assist identifying and regulating the countries sovereignty in the cyber network.

2. Enhancing the joint cooperation between the tax authorities.

3. Exchanging information without the need of a per-notice and permission from the court and keeping the information in total confidentiality except for the concerned parties.

4. Establishing an Electronic Permanent Establishment (EPE) as an option for international taxation on profits of cross border business transactions in the context of digital economy and the EPE concept needs to be aligned with new technology.

5. Implementing the above mentioned through bilateral or multilateral agreements.

\footnotetext{
35 Spinosa, L. and Chand, V., 2018. A Long-Term Solution for Taxing Digitalized Business Models: Should the Permanent Establishment Definition Be Modified to Resolve the Issue or Should the Focus Be on a Shared Taxing Rights Mechanism?. Intertax, 46(6), pp.476-494

36 Alejandro Vesperinas Juan, OECD Releases Discussion Draft On Attribution Of Profits To Pes, 2017, https://tpinttax.wordpress.com/2017/08/09/oecd-releases-discussion-drafts-on-guidance-on-profit-splits-andattribution-of-profits-to-pes/
} 
In the domestic level:

1. The country must have its own server and provide access to electronic application, for both domestic and foreign users. Consequently, we will be able to effectively allocate taxing jurisdiction and revenue to source countries, and eliminate the mobility of servers offers tax planning opportunities for shifting income outside of residence countries.

2. The country has to identify the users identity by giving them a specific license number through applying the Internet Protocol version 6 (IPv6). And this version will be discussed in more details in chapter five.

3. From the administrative perspective, the country must create an Information Technology (IT) administrative system that includes official officers in order to monitor and follow the electronic transactions.

4. The users must get a pre-approval from the concerned sides before entering the Emarket, and they have to meet all the registration requirements.

5. The users must get an adequate time to meet all the needed requirements and to recorrect the legal status.

6. Any violation on the E-market entering rules, the IT officers will do what must; giving a notice at first and ending up even with blocking.

7. Using the database of the server as evidence in case if there is any doubt related to the tax report.

\section{References:}

Alejandro Vesperinas Juan, OECD RELEASES DISCUSSION DRAFT ON ATTRIBUTION OF PROFITS TO PES, 2017, https://tpinttax.wordpress.com/2017/08/09/oecd-releases-discussion-drafts-on-guidance-on-profit-splits-andattribution-of-profits-to-pes/

Aless, A., j. DE Goede and W. Wijnen (2011), “The Treatment of Services in Tax Treaties”, Bulletin for International Taxation, 2012, Vol. 66, No. 1.

Beretta, G., 2017. The Brisal and KBC Finance Decision: Once Again the CJEU Assesses the Compatibility with EU Law of Gross Withholding Taxation of Non-residents. EC Tax Review, 26(4), pp.193-200

Bruins et al. (1923), Report on Double Taxation submitted to the Financial Committee, No. E.F.S.73.F.19, League of Nations, Geneva

Ching Khee, T. and Syrett, H., 2017. Impact of OECD Beps Action 7 Proposals on Modification of Articles 5 (4), 5 (5) and 5 (6) of OECD Model Convention-An Evaluation of Action 7 on the Future of Intra-Group Transactions and Business Models of MNEs in their Cross-Border Investments

Cui, W., 2015. Taxation of Non-residents' Capital Gains. United Nations Handbook on Selected Issues in Protecting the Tax Base of developing Countries, pp.107-154.

Kane, M.A., 2017. A US Perspective on the Relevance of the OECD BEPS Project to the Taxation of Nonresidents. New Zealand Law Review, 2017(2), pp.175-205

Lincoln, I.V., 2017. Approaches to Attribution of Profits in International Corporate Permanent Establishments' Taxable Separate Entities.

Miller, A. and Oats, L., 2016. Principles of international taxation. Bloomsbury Publishing.

Monica Gianni,The OECD's Flawed and Dated Approach to Computer Servers Creating Permanent Establishments 17 Vand. J. Ent. \& Tech. L. 1 (2014), available at http://scholarship.law.ufl.edu/facultypub/608

Neubig, T.S. and Slemrod, J.B., 2017. A Tax-Systems Perspective on Recent Global Tax Initiatives 2008, OECD Publishing, Paris. https://www.oecd.org/tax/transfer-pricing/41031455.pdf

Reimer, E., Schmid, S. and Orell, M. eds., 2018. Permanent establishments: a domestic taxation, bilateral tax treaty and OECD perspective. Kluwer Law International BV.

Spinosa, L. and Chand, V., 2018. A Long-Term Solution for Taxing Digitalized Business Models: Should the Permanent Establishment Definition Be Modified to Resolve the Issue or Should the Focus Be on a Shared Taxing Rights Mechanism?. Intertax, 46(6), pp.476-494 
Srivastava, D.K., 2018. Taxation of E-Commerce: Problems and Possible Solutions. In Contemporary Issues in International Law (pp. 447-457). Springer, Singapore.

Yapar, B.K., Bayrakdar, S. and Yapar, M., 2015. The role of taxation problems on the development of e-commerce. Procedia-Social and Behavioral Sciences, 195, pp.642-648.

\section{OECD Publications:}

OECD MC Article 7, paragraph seven; OECD, commentaries on the articles of the model tax convention, MODEL TAX CONVENTION (CONDENSED VERSION) - ISBN 978-92-64-08948-8 - (C) OECD 2010

OECD Transfer Pricing Guidelines for Multinational Enterprises and Tax Administrations 2017, OECD Publishing, Paris http://www.oecd.org/tax/transfer-pricing/oecd-transfer-pricing-guidelines-for-multinational-enterprisesand-tax-administrations-20769717.htm

OECD, (BEPS Action 7) on June 2017 for public comments" http://www.oecd.org/ctp/transfer-pricing/publiccomments-received-on-beps-discussion-drafts-on-attribution-profits-permanent-establishments-andtransactional-profit-splits.htm

OECD, Are the Current Treaty Rules for Taxing Business Profits Appropriate for E-Commerce?, Report, www.oecd.org/tax/treaties/35869032.pdf

OECD, commentaries on the articles of the model tax convention, MODEL TAX CONVENTION (CONDENSED VERSION) - ISBN 978-92-64-08948-8 - (C) OECD 2010 http://www.oecd.org/berlin/publikationen/43324465.pdf

OECD, Paragraph 15 by OECD MTC Article 7; OECD, commentaries on the articles of the model tax convention, MODEL TAX CONVENTION (CONDENSED VERSION) - ISBN 978-92-64-08948-8 - C) OECD 2010

OECD, Paragraphs 13, 19 and 20 of OECD Article 7; OECD, commentaries on the articles of the model tax convention, MODEL TAX CONVENTION (CONDENSED VERSION) - ISBN 978-92-64-08948-8 - (C) OECD 2010

OECD, Report On The Attribution of Profits to Permanent Establishments 